\title{
The Impact of Project Activities on the Cultivation of Ecological Citizenship in a High School Climate Change Club
}

\author{
Woo-Yong Park \\ Department of Science Education, Seoul National University, \\ Seoul, Republic of Korea \\ earthpark@snu.ac.kr \\ Chan-Jong Kim \\ Corresponding author, \\ Department of Earth Science Education, Seoul National University, \\ Seoul, Republic of Korea \\ chajokim@snu.ac.kr
}

Received: 14 February 2020 | Revised: 22 April 2020, 30 May 2020 | Accepted: 31 May 2020

\begin{abstract}
This research explored the characteristics of students' activities and their artifacts during their participation in climate change club projects and investigated the impacts of the club project participation on students' ecological citizenship. Climate change club projects were developed to help students understand climate change, investigate climate change issues, and plan and participate in social actions. Participants developed scientific models of causes of climate change and were expected to develop the own perspectives about socio-scientific issues related to climate change. Five types of competences of ecological citizenship were targeted through club activities: knowledge and understanding, responsibility, justice, sustainability, and participation. Researchers found activities were student centered and interactive and artifacts generated by students were resources for social action. Climate change club activities demonstrated the potential for student participation in club projects to promote competence for mitigating climate change among future generations by fostering a new form of citizenship: ecological citizenship.
\end{abstract}




\section{초록}

이 연구에서는 고등학교 기후변화 동아리 프로젝트에 참여한 학생들의 활동 및 산 출물에서 보이는 특성을 탐색하고, 이 프로젝트 활동이 학생들의 생태시민성 함양 에 미치는 영향을 조사하였다. 기후변화 동아리 프로젝트 개발의 주안점은 학생들 이 기후변화를 이해하고, 기후변화 쟁점을 조사하며, 사회적 실천을 계획하고 참여 할 수 있도록 도움을 주는 데에 있다. 이를 통해 참여자들이 기후변화의 원인에 대 한 과학적 모델을 개발하고, 기후변화와 연관된 과학관련 사회적 이슈에 대한 개 인의 가치관을 발전시킬 수 있을 것으로 기대되었다. 동아리 활동은 지식과 이해, 책무성, 정의, 지속가능성, 참여라는 생태시민성의 다섯 가지 영역을 중점으로 하 였으며, 학생 중심의 상호작용 활동으로, 학생이 제작한 산출물들은 사회적 실천 을 위한 밑거름이 되었다. 기후변화 동아리 활동은 새로운 시민상으로써의 생태시 민 양성을 통해, 미래 세대인 학생들이 기후변화 완화를 위한 역량을 함양할 수 있 다는 가능성을 보여주었다.

\section{Keywords}

climate change education - ecological citizenship - student club project Socio-Scientific Issues (SSI) education

\section{Introduction}

Since the Industrial Revolution, humankind has made remarkable progress that cannot compare to any other time in history. However, successful modernization has systematically disregarded the consequences for nature and human beings, which has resulted in the issue of climate change as a product (Beck, 1999/2010). The process of modernization toward a "rich society" has resulted in a "risk society" in which unintended side effects threaten the very survival of industrial society (Hong, 2016). This has resulted in climate change, which poses a very fatal risk to all mankind.

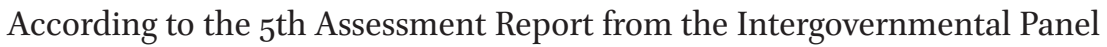
on Climate Change (IPCC), the global climate system's warming is obvious, with the average global temperature having increased about $0.85^{\circ} \mathrm{C}$ since $188 \mathrm{o}$ and the current average sea level having risen about $19 \mathrm{~cm}$ since 1901. It is particularly clear that humans are affecting the climate system, not only is the increase deepening, but this worsening impact is being continuously observed across the continents and oceans of Earth. If man-made greenhouse gas emissions continue to disrupt the climate, the planet will face the risk of serious and widespread irreversible impacts (IPCC, 2014). 
As one of the main countermeasures to alleviate the climate change problem, an educational approach is thought to be necessary, given that the causes of the climate change problems currently being experienced by mankind ultimately stem from human collective activities. However, by letting students remain at a level of knowledge acquisition and understanding that is not focused on the growing issues of climate change (Shin, 2017), schools are not fully addressing either climate change content or its countermeasures (Kim \& Choi, 2010).

In particular, climate change education programs that have been developed and applied to educational sites are mostly elementary school-level programs. They generally decrease as school level increases, thus creating little progress in high schools (Park, 2019). Granted, there are practical difficulties in bringing climate change education into regular classes, as the content of the nation's high schools all follows the same national curriculum, which is directly linked to the sensitive subject of college entrance. Given these circumstances, this study proposes club activities as a means to overcome limitations in the implementation of high school curricula and education programs on climate change. In the Korean National Curriculum, club activities emphasize the realization of practical and voluntary activities by students, thereby promoting sound development of the mind and body while focusing on education. This concept was developed in order to foster the development of social leaders through diverse cultural understanding and exploration (Ministry of Education, 2015). Therefore, through voluntary club activities at schools, continuous learning and practice on environmental issues such as climate change can be implemented (Kim \& Shin, 2012).

On the other hand, environmental issues such as climate change are problems on the global level, which are difficult to solve at the national level or within traditional civil concepts. This fact has led to discussions about forming a new citizenship in society, where citizens who may have directly caused environmental problems prior to education can now successfully allow an ecological adjustment and form continuous sound reconstruction (Kim, 2013). Against this backdrop, this newly emerged ecological citizenship includes the formation of a new framework aimed at educating citizens who can solve environmental problems in terms of justice, as well as fostering the conceptual reconstruction of citizenship as the subject of active implementation. This study noted that cultivating ecological citizenship must be included as an educational objective in programs that approach the climate change issue educationally. This insight can allow students to feel responsibility as global citizens, be aware of environmental issues and of themselves as citizens of the future, foster knowledge of how individual and regional problems relate to global environmental issues, and develop individuals' ability to act voluntarily. 
In the light of the need to bring the concept of ecological citizenship to the school site in order to look at climate change issues from an ecological point of view amid rapid globalization, this study seeks to explore the ways in which this activity can affect the cultivation of ecological citizenship through the development and application of active project-type programs within climate change clubs in high schools. Thus, in order to achieve the objectives of this study, two research questions were formulated:

1. What are the characteristics of students' activities and artifacts during climate change club projects?

2. How do the project activities in a high school climate change club affect the cultivation of students' ecological citizenship?

\section{Theoretical Background}

\subsection{Climate Change Education}

The world is already affected by climate change that is irrevocably severe, and it is causing negative impacts in many areas (Stern, 2006). Given these circumstances, it is no longer a subject of debate about whether it is really happening, what is happening, or how much mankind bears responsibility for current climate change (UNDP, 2007). At the heart of today's debate instead is now how to address climate change (Yoon, 2009). One of the most effective ways to do this is through public participation (Giddens, 2009). In this study, we believe that public participation is necessary for the general public to educate themselves about climate change and how to effectively respond to it.

Developing and applying education on environmental issues such as climate change is an inevitable duty that was initially designed to help students, who are the future protagonists, thrive in a brighter and more hopeful future (Kim, 2009). Accordingly, education policies and curricula need to promote knowledge and understanding of the causes and effects of climate change while promoting strategies for coping with climate change in terms of mitigation and adaptation. Furthermore, appropriate practice-oriented teaching methods should be used to enhance knowledge, skills, values, and attitudes for effective mitigation (Korean National Commission for UNESCO, 2012).

However, despite the need for climate change education, our schools have failed to fully address climate change and the responses focused on it (Choi \& Kim, 2008). In terms of how frequently climate change is dealt with, based on the achievement standards of the 2015 revised curriculum, it is present twice: once in middle school geography and once in high school science. In both contexts, it remains knowledge-oriented content such as "evaluation of 
regional and international efforts to investigate and address the causes of climate change at the global level" and "evaluation of the pros and cons of alternative energy from the perspective of solving global environmental problems caused by climate change" (Shin, 2017).

The project activities of the high school climate change club in this study deviated from the limits of school climate change education insofar as that they were based on the goals and directions pursued by climate change education. This study defines climate change education as

education that is aimed at knowing and understanding the causes and effects of climate change problems, giving one the ability to reflect on one's current behavior and to respond to problems based on one's own individual values, and cultivating the competence to actively participate in personal and social practices.

From the above definition, the goals of climate change education should include, but are not limited to, knowledge and understanding of climate change, establishment of individual values, and participation in personal and social practice. Therefore, they were subsequently applied throughout this study as the basic background concepts of developing high school climate change club project activities.

\subsection{Characteristics of Project Learning and Application to Club Activities}

Project learning is a method in which learners select the topics they want to explore. This particular method allows students to examine the topics in depth by choosing the appropriate method of exploration or problem solving and then solving problems by organizing the materials and results obtained in the course of the exploration. In this way, learners obtain knowledge and problemsolving skills throughout the entire process (Ministry of Education and Science Technology, 2009). Project learning activities are of distinct value in comparison to structured classes, as students' inclination to take advantage of acquired functions can be enhanced through project activities (Katz \& Chad, 2000).

However, unlike traditional teacher-led teaching methods, the length of time required for project learning depends on the subject, and in most cases it can take weeks or even months to complete. In addition, the experience of learning is determined by the interest of the students rather than by the guidance of their teachers. As the project progresses, the production and modification of the output to show the problem-solving process is repeated (Helm \& Katz, 2001). Nevertheless, project learning is task-centric, as students effectively apply a series of processes to address challenges such as the collection and 
analysis of information and the presentation of solutions (Krajcik et al., 1994). Due to these characteristics, project learning is a more effective application in freer activities, such as club activities, than it is in traditional classrooms (Kim, 2016).

The fact that most high school textbooks in Korea are produced according to the national curriculum helps ensure that students remain interested in regular and college-entrance examinations. Therefore, bringing project-learning activities that are centered on non-traditional subjects into traditional learning classrooms has usually been seen as a burden. Because of this, the club's project activities in this study were conducted with students who gathered according to their common interest in climate change. In a school club, which can be relatively free from the pre-arranged curriculum, the possibility of longterm activities exists. Therefore teachers and students can exercise freedom and creativity as they think deeply and collectively about the subject of climate change.

\subsection{Ecological Citizenship}

Ecological citizenship is drawing attention as a new form of citizenship suitable for responding to problems such as the global climate change crisis, which is now considered insoluble, using temporary or peripheral perspectives and approaches. Dobson (2003) saw the realm of citizenship as a new "ecosystemic" concept in addition to the existing idea of citizenship, and introduced justice as a key concept.

Behind the discussion and appearance of ecological citizenship are globalization and the personalization of environmental responsibility (Kim, 2012). The traditional concept of citizenship has been defined by the relationship between individuals and countries; however, the terms of globalization have called for a change in this nature of citizenship. The concept of citizenship has now been extended without the limitation of the legal basis for the rights and responsibilities that have been granted to individuals by the state (Kim, 2011).

A sustainable society cannot be achieved only by institutional change; nonetheless there has been growth of widespread acceptance of the need for individual commitment to realize the concept of ecological value (Carter, 2001). This approach of placing individuals at the center of responsibility in the solution of global environmental problems is a different approach to causing and resolving environmental degradation in industrial societies. In the personalization of responsibilities era (Beck, 1993/1998), individuals reflect on their actions as citizens who know that their actions could affect the environment and fulfill their responsibilities. 
Attempting a new definition of citizenship, Dobson (2003) argues that it is ultimately aimed toward post-cosmopolitanism, which can be attained through ecological citizenship. Ecological citizenship has an ecological appearance in the new framework of post-cosmopolitanism that is very distinct from traditional citizenship, liberalism, and civil republicanism. Traditional citizenship has a contractual relationship to rights and responsibilities that emphasizes a public domain that is based on discriminatory territoriality, while post-cosmopolitanism emphasizes non-contractual obligations and responsibilities in both the public and private arenas. It is grounded in such virtues as consideration, solidarity, and tolerance, and it is non-discriminatory and not bound to territoriality (Dobson, 2003).

What are the competences an ecological citizen should have? Oxfam (2006) emphasized helping people to become global citizens as a goal of education for sustainability. Through this, we can see that global citizens and ecological citizens are very similar, in that educational programs for sustainability are oriented toward qualities of in-depth thought about environmental issues and integrated levels. Oxfam (2006) presented function, knowledge and understanding, and value and attitude as the essential qualities of global citizens. Finally, Karatekin and Uysal (2018) emphasized responsibility, justice, sustainability, and participation as important aspects of ecological citizenship that help develop tools for measuring ecological citizenship.

Since the ecological crisis situation in modern society poses an economic and political threat in addition to the environmental issues, human beings, the main agents of responsibility and resolution, will have to take immediate action. In the demands of these times, ecological citizenship can be applied to real-life problem situations such as climate change (Kim, 2013) and can be the ultimate solution to overcome the global environmental crisis (Kim \& Shin, 2012). This study aimed at defining what qualities were required for high school students to become ecological citizens, especially considering that high school students were required to participate in project activities in a climate change club, with the final purpose of these activities being the cultivation of ecological citizenship.

Given the definition of climate change education in the Theoretical Background section and noting that high school students are the subjects of this study who are aiming to gain the qualities of ecological citizenship, the four aspects of ecological citizenship that are emphasized by Karatekin and Uysal (2018) were considered appropriate as qualities that high school students should have as ecological citizens. In addition, the knowledge and understanding aspect was added because of the fundamental importance of scientific understanding in action 


\section{Competence Definition}

Knowledge and understanding Responsibility

Justice

Sustainability

Participation
Attention to environmental issues such as climate change, and understanding its causes, impacts, and characteristics Responsibility for everything and everyone with whom one has shared and will share the ecosystem Social justice to accept ecological citizens' environmental obligations based on the relationship between all citizens Controlling one's behavior that can affect the ecosystem, and working for a sustainable environment and society Individual, social, and political participatory behaviors for solving environmental problems

competences (Bishop \& Scott, 1998). The competences for high school students as ecological citizens are defined and summarized as Table 1.

\section{$3 \quad$ Method}

\subsection{Development of Activities}

Following this definition of climate change education given in the Theoretical Background section, we set three goals for the program:

1. Understanding the causes and effects of climate change problems

2. Establishing an individual's values in order to effectively respond to these problems

3. Cultivating the ability to participate in personal and social practices

In the process of designing the program, each of these three goals was set as a step-by-step theme of the program: The first step allowed students to understand climate change scientifically and the second step was designed to help students construct a perspective of looking at a problem by investigating the climate change issues near them. In the third step, through the activities and outcomes of the previous two steps, we organized activities to help students develop the ability to participate by planning and implementing their own personal or/and social actions. Figure 1 shows each step and the weekly plan of the activities that were developed, with the three-step activity for seven weeks.

The first step of the activities was aimed at understanding climate change, which lasted for two weeks. In the first week, the teacher introduced the 


\section{Step 1: Understanding climate change}

Week 1: Activities guidance, climate change introduction, group formation

Week 2: What are the causes of climate change? - Scientific modeling

\section{Step 2: Investigating the climate change issues}

Week 3: Selecting issues and investigating them

Week 4: Presentation and discussion of issues selected by each group

Step 3: Planning and participating in social practice

Weeks 5 and 6: Develop our social practice plan to fight climate change

Week 7: Implementation of practice and evaluation of activities

FIGURE 1 Outline of developed project activities in high school climate change club

program and the current climate change situation. The teacher also organized small groups of three or four students where they talked about each other's interests, thus enhancing bonding among students. In the second week, participants constructed a model explaining the causes of climate change. Students investigated the scientific data on climate change and developed explanatory models about the causes of climate change at the personal, small-group, and whole-class levels.

The second step of the activities lasted for two weeks, with the goal of investigating ongoing climate change issues. The third week consisted of activities to explore issues the students' daily lives, which allowed them to select issues to investigate. Each group investigated their chosen issue and then presented the results of their investigation during the week four activities. This step was intended to allow students to explore the climate change situation around 
them and foster personal values and perspectives regarding climate change through interactions with friends and teachers focused on the crisis of climate change and environmental actions.

The last step of activities was aimed at planning and participating in social practice. The students had an opportunity to participate in social practice to mitigate climate change at the high school level. Students investigated current Korean and international cases in weeks five and six, and gradually elaborated social action plans and preparations for these plans. In the seventh week, students were able to evaluate the entire club project, along with their feelings about the actual social practice.

The project activities developed in this study were based on existing projectlearning methods, but they also had some advanced aspects. Project learning generally involves exploring topics and identifying problems over a long period of time in order to develop and apply solutions, and is usually focused on acquiring knowledge. The project activities in this study had general components of project learning but also included activities for action for climate change as social practice.

\subsection{Participants}

This study was conducted at Q High School located in a medium city near Seoul, Republic of Korea. Students who attend Q High School generally have high academic achievements and relatively high motivation levels, as well as high expectations for participation in learning and club activities. They also study hard in order to have outstanding academic performance and to enroll universities with high reputations.

Q High School is a science-focused school with a good environment for planning and implementing a number of science-related project activities. Science-focused schools have a curriculum that focuses on mathematics and science with the goal of nurturing excellent science talent. Students can take science-related special and liberal arts courses. In addition, students are participating in differentiated science and mathematics classes, which are different from those at general high schools because individual research and experiment-oriented education are being conducted.

The climate change club that is the subject of this study was organized as an environmental project on the theme of climate change at Q High School. Student participation was voluntary. There were 10 participants, all of whom were in 1oth grade.

\subsection{Data Collection and Analysis}

This study collected data using pre- and post-questionnaires for ecological citizenship, students' artifacts from their activities, field notes, and in-depth 
interviews. First, the questionnaire for measuring ecological citizenship developed by Karatekin and Uysal (2018) was first translated into Korean and then modified and organized according to the level of the high school students and considering the contexts of Korea. The questionnaire consists of 24 questions and it was used for pre- and post-survey in order to identify the changes after the club project activities in terms of ecological citizenship. However, since there were only 10 participants, the survey results were only used to identify overall changes in ecological citizenship and to develop questions and select interviewees for in-depth interviews conducted after all the activities were completed.

Second, the students' activity artifacts were collected and analyzed to understand how participants understood the intended goals, content, and scope of the activities as well as to examine the characteristics of their participation in these activities. They were also used to identify how activities affected the cultivation of ecological citizenship. These results were then also used to develop questions and select candidates for in-depth interviews.

Third, we observed and took field notes of participants' activities and recorded major remarks, actions, and participation of individual students. This allowed us to identify each participant's ideas, roles, and contributions. In addition, field notes were utilized as an aid to prepare questions and select candidates for in-depth interviews and to review students' thoughts.

Fourth, within two weeks of the end of the activities, in-depth interviews were conducted. Six students were chosen based on the pre- and postquestionnaires, the results of each activity, and the field notes for measuring ecological citizenship. The criteria of choosing students were a substantial difference between pre- and post-questionnaires and participation levels during the activities. In-depth interviews were semi-structured, and conducted individually. Interview guides included questions focused on exploring the reasons why students' answers in the post-questionnaire had changed from the pre-questionnaire and their experiences in and artifacts from each step of the activities. During the interviews, additional questions were used when we needed further information. Each interview lasted around 40 to 50 minutes, and all interviews were recorded and transcribed. The researchers read the transcribed interview data several times and analyzed them into five categories based on the competences for high school students as an ecological citizen defined in this study. For example, for participation, since it is about personal, social, and political participatory behaviors, we excerpted the relevant parts of the interview and classified them. After that, using the details of the interview data we categorized them into five themes, describing the characteristics of the relevant aspects as research results.

In order to ensure the validity of the analysis results in the qualitative analysis of the collected data, we used the following strategies. First, through 
triangulation, different types of data were compared for one participant to verify whether they matched. That is, for example, when looking at the change of particular student's ecological citizenship, we compared that student's questionnaire, artifacts of activities, field notes, and in-depth interview. Second, through a member check, participants were informed of the researcher's interpretation of the data collected from them and confirmed that it was correct. This particular strategy was used in an in-depth interview to confirm the interpretation of the questionnaire, the artifacts of activities, and the field notes, and to use this to continue the interview questions. Finally, we performed four separate peer examinations with seven science education researchers during the analysis by sharing the results of the analysis and checking the validity of the categorization.

\section{$4 \quad$ Results}

Research results were described in two parts: (1) the characteristics of students' activities and artifacts during climate change club projects and (2) the cultivation of ecological citizenship.

\subsection{Characteristics of Participants' Activities and Artifacts}

The characteristics of participants' activities and artifacts were summarized according to the steps of club activities.

\subsubsection{Step 1: Understanding Climate Change}

At this step, students participated in social construction of scientific models activities (Kim et al., 2017) and, created explanation models for the causes of climate change at the personal, small-group and whole-class levels. Examples of personal models created by students are shown in Figure 2. They commonly described the causes of climate change as human activities that gain energy mainly by consuming fossil fuels, such as industrial processes and car use, and from which come the emission of greenhouse gases (carbon dioxide, etc.).

After the creation of personal models, students created an agreed-upon small group model through a collective activity (Figure 3). The explanation models of the causes of climate change, completed through the social consensus process, reflect the $\mathrm{CO}_{2}, \mathrm{CH}_{4}, \mathrm{~N}_{2} \mathrm{O}$, and freon gases (PFC s, $\mathrm{HFC} \mathrm{s}, \mathrm{SF}_{6}$ ) proposed by most personal models.

Specifically, the characteristics of each group's model are as follows. The model created by Group 1 not only explained that greenhouse gases emitted from industrial processes and motor vehicle operations contributed to climate 

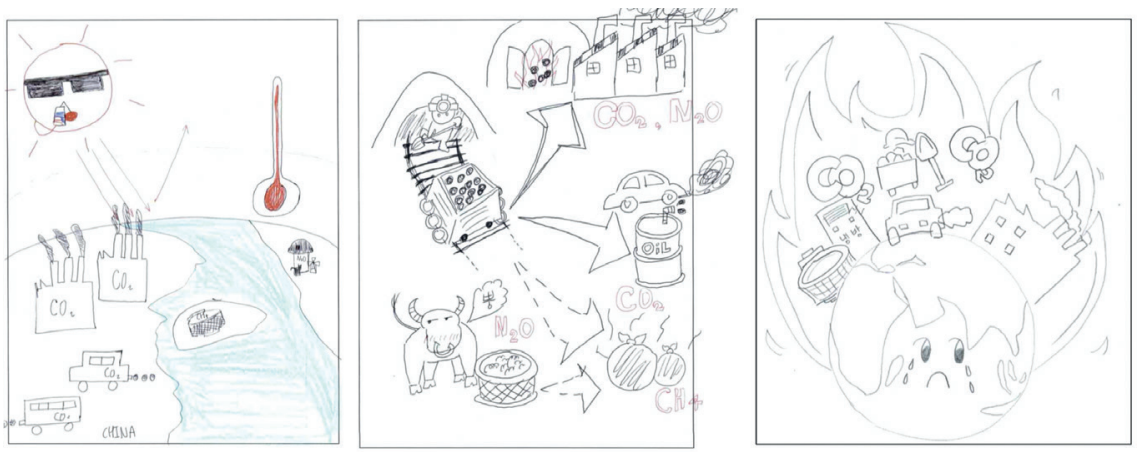

FIGURE 2 Examples of personal models describing the causes of climate change
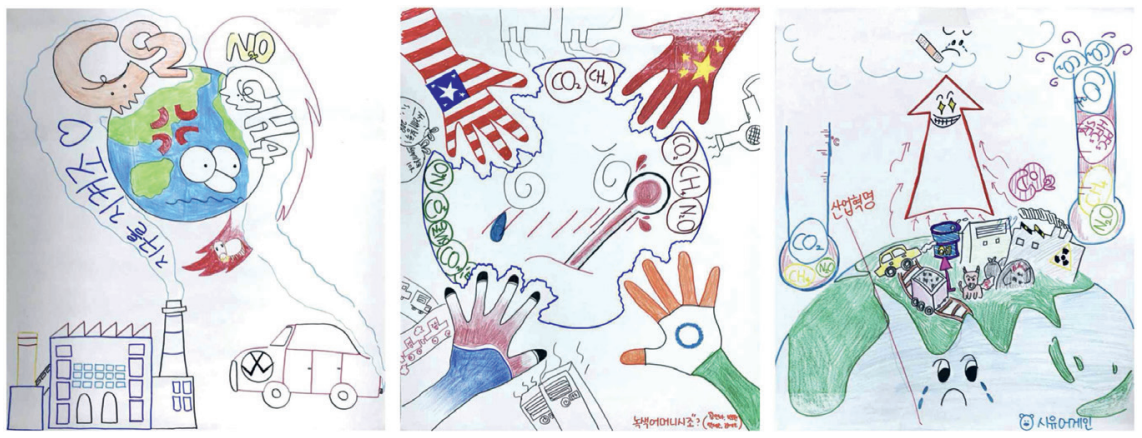

FIGURE 3 Group models describing the causes of climate change (Groups 1-3 from left to right)

change, but it also expressed different amounts of greenhouse gas labeling, depending upon the extent to which they contribute to climate change. The model created by Group 2 also highlighted that industrial processes, waste emissions, car operations, and air-conditioning use and produce greenhouse gases, indicating that countries such as the United States, China, India, and South Korea all have a huge impact on climate change. Finally, according to the model created by Group 3, the use of fossil fuels to produce energy produces greenhouse gases, which has increased the greenhouse effect, resulting in climate change. In addition, it is impressive that the model emphasized that greenhouse gas emissions were low before the Industrial Revolution, but later became high enough to overflow.

After each group posted its model in front of the classroom and presented, students compared the models to each other, creating one final model through a large group activity. The final, consensus model was then documented to explain the causes of climate change, concluding that 
since the Industrial Revolution, the use of fossil fuels such as oil, coal, and natural gas has exploded, and greenhouse gases have been released, causing the average temperature of the earth to rise sharply, thus causing climate change.

Through the process of creating the final model, students were able to explain the cause of climate change as an agreed-upon concept. With their unified agreement, this model explained the cause of climate change was indiscriminate emission of greenhouse gases through human activities, which was their central concept, underlying the execution of the remaining phases of the climate change club's project.

\subsubsection{Step 2: Investigating the Climate Change Issues}

In the second step of the activities, students selected local issues to investigate regarding the climate change situation. This included developing plans, implementing them into practice and sharing the results together. For Group 1, they chose trash as their issue and planned and implemented the "Let's reduce trash!" activity for three weeks. In the first week, the members checked the kind of garbage that they produced in schools and found that plastics made up the largest amount of waste. In the second week, they conducted personal practice through the use of tumblers instead of disposable plastic cups. In the third and final week, they organized actions at the individual level, including water saving, not throwing waste away, and unplugging electrical appliances when they are not used as their focus.

Group 2 planned an activity to measure school members' thoughts on environmental issues such as climate change and subsequently conducted surveys with both students and teachers. The survey questions were:

1. Can our country and the earth's environmental problems be solved in the future?

2. Do you think you are doing the right thing to solve environmental problems?

After analyzing the survey responses, participants in Group 2 agreed that in order to change people's perceptions of environmental issues, actions such as education and campaigns are necessary, and that negative perceptions do not help solve problems.

Group 3 focused on the issue that daily disposal of garbage can cause problems in relation to the issue of climate change. Therefore, the members asked their classmates about their awareness of the seriousness of climate change and their awareness of the disposal of garbage, handling processes, and personal practices. Based on the results, they concluded that their friends understood 
13 June
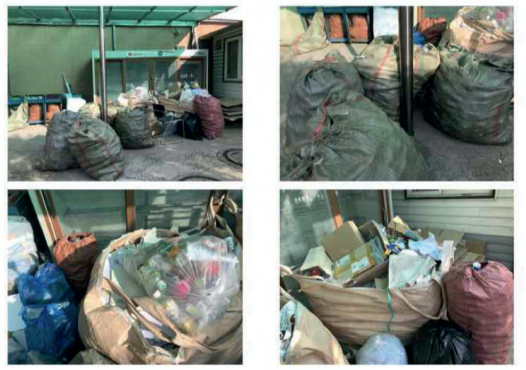

27 June
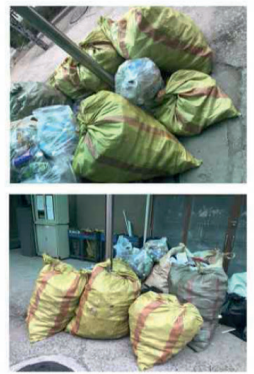
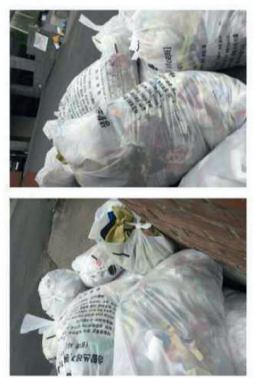

20 June

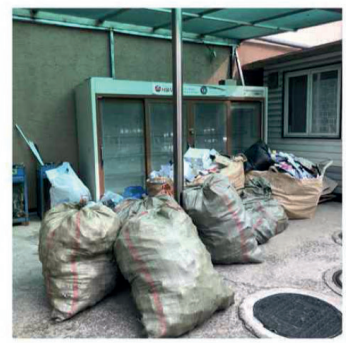

17 July

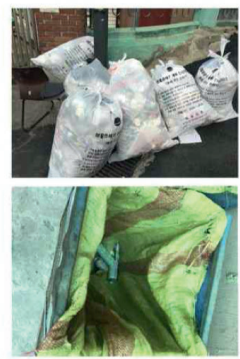

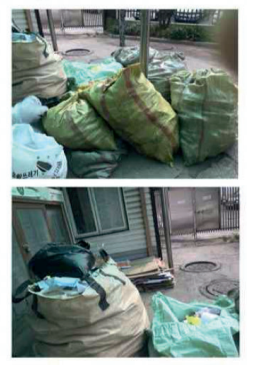

FIGURE 4 Survey of the amount of garbage discarded at school

that the climate change issue was serious. They also had full confidence that they understood the concept of trash worsening the climate change problem.

In addition, Group 3 visited the garbage collection area at the school for four weeks, as seen in Figure 4, in order to take pictures of the designated garbage collection day and to further investigate the types of garbage. They also investigated the amounts and types of garbage discarded at the school, which they presented in their results, showing that paper and ordinary trash constituted the largest amount, followed by plastic waste. Their conclusion was that when they threw garbage out in their classroom it never appeared to be substantial; however, when they looked at the amount gathered in the garbage collection site as a whole, it appeared that a large amount of garbage was being thrown out every week.

The main characteristic of the second step is students' attention to problems (e.g., disposal of garbage and problems with plastics) at the personal level in daily life that affect climate change. From these problems, students were able to explore climate change issues that were taking place near them. By actual investigation, they gained insights on climate change issues and were all able to recognize that these issues were all around them. 
4.1.3 Step 3: Planning and Participating in Social Practice

The third step of the activity was aimed at planning and directly participating in social practices in response to climate change. Starting with an exploration of the current climate change response actions already put into practice, the students were able to take an initiative in organizing and implementing social practices that they could realize at the high school level. At the beginning of the third step, students showed a rather passive attitude in proposing social practice, only staying in efforts that the group members could do personally. However, after several rounds of discussion, students expanded and elaborated the scope of their actions in response to climate change.

In view of the school schedule and duration of preparation, the students finally agreed to produce posters to spread information about the seriousness of climate change and carry out campaign activities throughout the school. To this end, the basic form was developed through sketching an idea for poster production, and locations for posting were found and promotional methods were determined. The promotional poster produced is shown in Figure 5 .

All activities in the third step were conducted at the initiative of the students, while the teachers participated in the settlement process and provided support at the school level. Posters completed for the campaign were posted in active places, such as school bulletin boards and in front of the school restaurant, as shown in Figure 6.
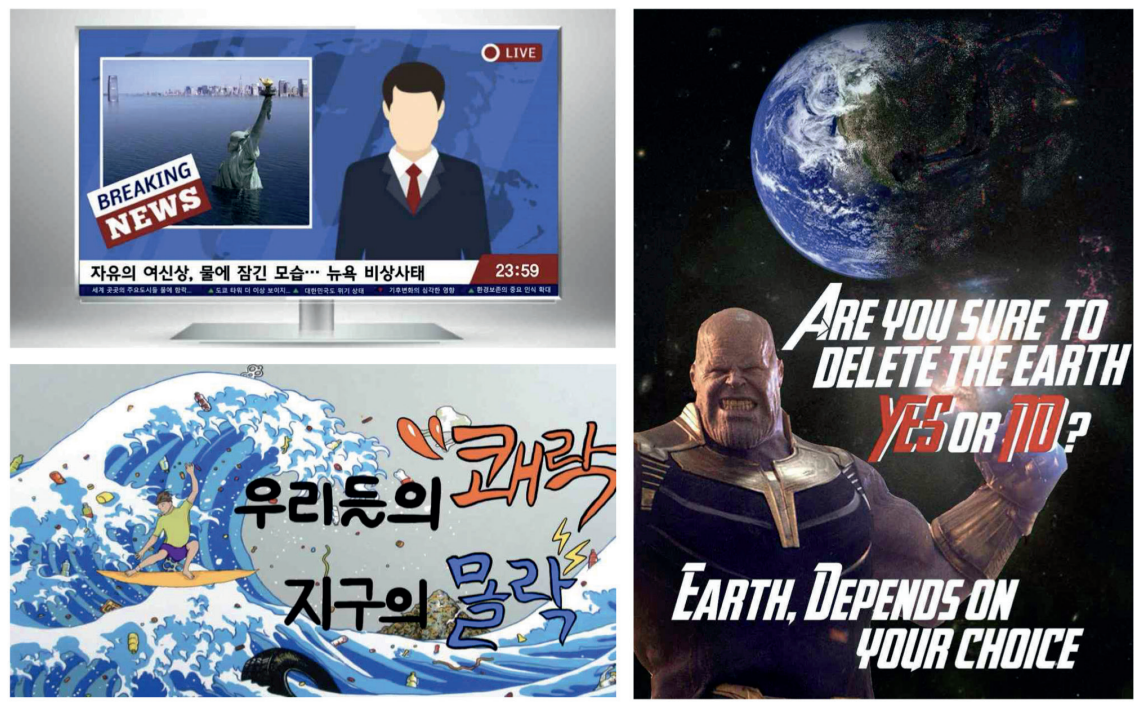

FIGURE 5 Three posters to give information about climate change problem made by students 


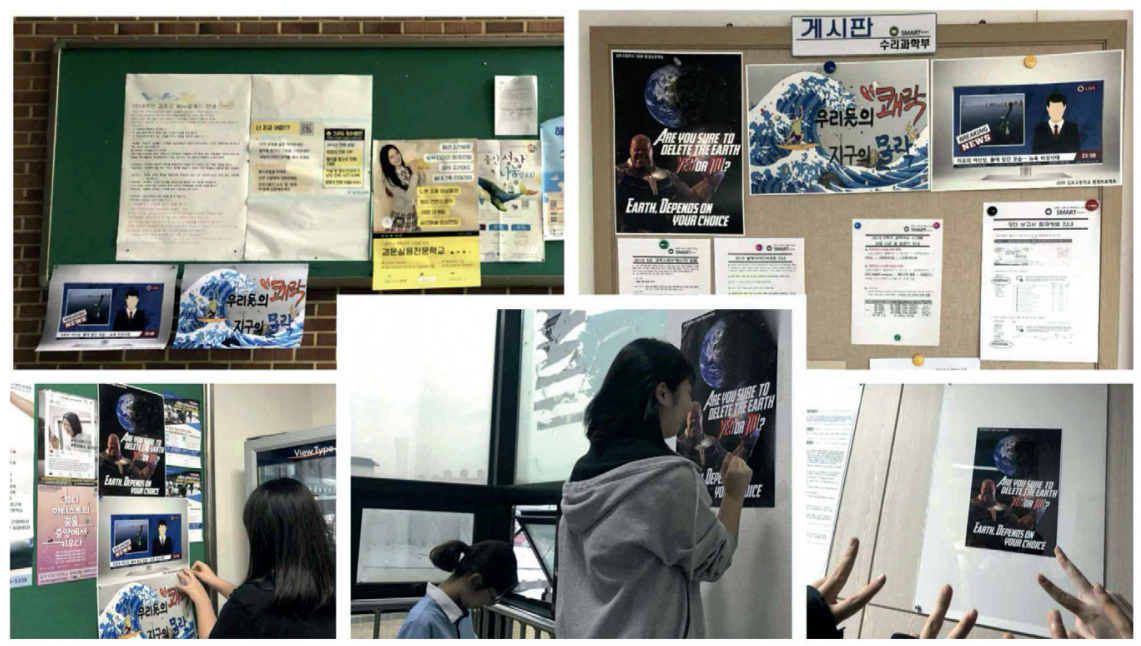

FIGURE 6 Poster placement and promotional activities campaign

In fact, in the third step of the activity, the scope of social practice implemented by students was limited to their school. Nevertheless, it is characteristic that students took the initiative in determining the methods and scope of social practice and conducted it without the intervention of a teacher.

\subsection{Cultivation of Ecological Citizenship}

To determine how high school climate change club project activities affected the cultivation of each aspect of ecological citizenship, in-depth interviews were conducted based on field notes, results of activities, and the pre- and post-questionnaires on ecological citizenship. In this section, the analysis results from the in-depth interviews will be described in terms of the following five aspects of competences that high school students should possess as ecological citizens: (1) knowledge and understanding, (2) responsibility, (3) justice, (4) sustainability, and (5) participation. Pseudonyms are given for all students who participated in interviews.

\subsubsection{Knowledge and Understanding}

For this aspect, we expected students to be interested in climate change and to know and understand its causes, effects, and characteristics. Participants' changes in knowledge and understanding of climate change could be categorized into two types: (1) reconfirming of existing knowledge and (2) deep understanding of the seriousness of climate change. In general, most participants understood the seriousness of climate change, with only one participant 
reconfirming the knowledge she had already known. The confidence of one participant, Yena, for example, improved in terms of knowledge and understanding. Before she joined the activity, Yena was not interested in climate change and thought that it was caused by natural phenomena. She had done little to solve environmental problems in her daily life, doing things such as using a car to go everywhere, even to places nearby. However, as she participated in the activities, she acquired new forms of knowledge based on climate change. This new information subsequently helped her realize that it originated from human activities that produce greenhouse gas emissions.

Yena: Before conducting this project, I used to think that the environment could change [naturally] depending on the situation; however, now I think that the climate is changing, because the environment is polluted by regular cars and air conditioners.

Researcher: Why did you change your mind?

Yena: I was really not interested in climate change before the environmental project, and I didn't really know what caused climate change. Nonetheless, I thought, well, maybe it just wouldn't change, but after conducting the environmental project, I realized that climate change is caused by what we humans are using for convenience.

Heji, a student who tries to save water or reduce waste in her daily life, replied that she had learned about the effects of climate change on the ecosystem, which were much larger than she had thought before participating in the activities.

Heji: I didn't know the impact of climate change was this serious, but it's really serious. I'll be an adult soon, and I'll continue to become more serious from then on ...

Researcher: So, did you feel that the risk of being affected by climate change is greater than you originally thought?

Heji: $\quad$ Yes, because I was able to learn more about things that I didn't know before ... It's affecting the ecosystem.

The club project activities of this study were organized to explore the causes of climate change and its effects and characteristics, expecting that the existing school climate change education would overcome limitations. As the cases of both Yena and Heji show, by participating in these activities, students were 
able to understand the causes of climate change, explore the effects of climate change problems, and perceive that the activities had a positive impact on their knowledge and understanding about climate change.

\subsubsection{Responsibility}

In this part, we emphasized responsibility for all living and non-living things that we have shared, currently share, and will share the ecosystem with. In terms of responsibility, all participants showed a tendency to increase awareness. In particular, they agreed that human beings are responsible for causing climate change and argued that alternatives to the current human lifestyle are needed. The following example of a student name Yerim shows how she came to believe that humans were responsible for environmental problems such as climate change. She also criticizes humans for forgetting the preciousness of nature, arguing that a better way of life is needed where humans think more about the environment. Lastly, she predicted that even in this current situation, people living on Earth would not be able to solve the problem, because they did not try to solve it when they first began to be aware of the irrevocable damage being caused.

Yerim: $\quad$... anyhow, it's humans who started the Industrial Revolution, and if you look at the root of everything, it's human responsibility.

Researcher: What is the relationship between man and nature?

Yerim: $\quad$ Nature would be better without humans

Researcher: Do you think it would be better without humans?

Yerim: Yes, I think ... now, human society has tamed nature for so long, I think it's natural to use nature's preciousness.

Researcher: Do you think that nature and human beings should live together? Yerim: Yes, many human civilizations have developed and many people now have their own thought. Isn't there something else that can help us live with better energy?

Students generally regard human responsibility for environmental issues such as climate change and disappointedly criticize humans for not being as responsible as they should be.

In particular, in the second step of the project, many groups investigated how people around them perceive climate change and environmental issues. In the process of investigating and sharing the current status of waste emissions, many found a gap between people's perceptions of the problem and their behavior. 


\subsubsection{Justice}

The competence of justice is about social justice, which relates to responsibility for the environment as an ecological citizen and how we view the problems of unfairness and inequality arising from environmental problems such as climate change. Participants' changes in this part could be categorized into two types: (1) finding that there is a close link between wealth imbalances between individuals or countries and their degree of risk from climate change and (2) understanding that natural disasters that occur to other people or in other countries are not irrelevant to us. Specifically, participants say that inequality in goods between countries can also be seen in the degree of risk from the climate change problem. For example, Eunmi believes that differences of climate change risk exist unfairly between developed and developing countries.

Eunmi: Developed countries have developed in the past and now, they say, "Let's reduce the damage." It feels as though they believe that we're all developed, so we can finally live safely, even though developing countries haven't yet developed. I think it's unfair.

Researcher: Does that mean that developing countries have just begun to develop, and with the addition of regulations on carbon emissions, it has become more difficult?

Eunmi: Yes, other (developed) countries are already grown, but developing countries are not grown yet, and climate change is still happening. Therefore, it poses a greater risk to developing countries.

In addition, through the project activities, students learned that the negative impact of climate change is spreading on the planet, and they saw examples of these problems from a perspective of social justice. This can be found in the following example from Yerim.

Yerim: In the news, there are often stories about typhoon and flood damage in other countries. I used to think, "That's what that country is like." However, climate change causes more damage and casualties.

Researcher: Did you change your minvd during the activity?

Yerim: $\quad$ Yes, my perception has changed. I thought it was a story that had nothing to do with me, but after I took part in the activity, my perception expanded to a global level. I think that's how it changed. 
In particular, when participating in the project, we can see that the activities affected the cultivation of ecological citizenship in terms of justice, given that a participant's perception of other countries' problems, which were originally thought to have nothing to do with them, has actually expanded to a global level.

\subsubsection{Sustainability}

As an ecological citizen, sustainability may regulate individuals' behavior that can affect the ecosystem and focuses on individual environmental actions. These are set in terms that are oriented toward a sustainable environment and society. Participants showed three types of change in this aspect: (1) actively changing individual behavior in daily life, (2) establishing personal awareness and willingness to practice, and (3) reflection on usual personal behavior. The following conversations with Yerim are examples of their participation in the project, in which they reflect on individual behavior and perform daily practices based on their perceptions.

Yerim: $\quad$ Because of doing this project, the use of disposable products is now sensitive. At home, disposable products remind me of this project.

Researcher: Do you think that leads to action?

Yerim: Yes, it often seems to increase in number. At first, I just remembered it once in a while, but these days, I think I often think of it. Instead of wooden chopsticks, I use metal chopsticks, or when something is plugged into an electrical outlet it tends to feels like it's still in use, so now, I just pull it out.

Researcher: Did you change after this project?

Yerim: Yeah, it's changed. Now I can recognize that my behavior is going to affect the environment. So, I don't want to let myself think that words and actions are different.

In addition, the experience of students participating in the activities provided them an opportunity to reflect on their personal behavior while changing their personal perceptions and practices in a positive way. The following example reveals that Minju has come to reflect on her behavior, thinking vaguely "well done" before joining the activity, then questioning "really doing so?" while participating in the project.

Researcher: When you thought about your personal behavior related to the environment, you said you were "doing well" at first, but after the activity, your answer changed to "not." Why? 
Minju: $\quad$ At first, I thought I was doing it, but now, while participating in the activities, I don't think I'm doing that much.

Researcher: Did you come to look at yourself?

Minju: $\quad$ Yeah, for example, I thought I'd be saving water or something, but I don't think that I actually saved any water.

These results appear to have been influenced to some extent by the students' individual values when looking at the problems during the second step of project activities as well as by the experience of social practice through the third step.

\subsubsection{Participation}

In this part, social and political participation in solving environmental problems, such as climate change, is seen as a competence. Participants' changes in the participation aspect can be categorized into three types: (1) improved willingness to participate, (2) inner conflict between the need for participation and the inability to participate in reality, and (3) great disappointment with the current situation, taking a negative position on participation. Generally, most participants showed an improved willingness in terms of participation. Minju especially played a leading role and showed an increased willingness to participate, taking part in each of the project activities. Due to her mother's influence, she usually tries to save energy and faithfully dispose of household waste, and is also interested in the environmental conservation.

Minju: I'm sure it has changed. I went home and talked about climate change to my family every day after the project activities.

Researcher: What did you talk about?

Minju: The climate has changed a lot now. It's changing and it's very serious. We talked about all the activities I had on that day.

Researcher: How did your family react?

Minju: I mostly talked to my mom, and she seemed very interested in protecting the environment. Before, I didn't really think I was polluting the environment, but now, every time I do something, I think a little bit about it. I think other people have to change, but I think they can't understand it.

On the contrary, while admitting that social practices such as campaigns and community activities are necessary, students like Eunmi, showed a negative attitude that such practices will not be meaningful. Eunmi predicted a dark future, saying the current situation in which the climate change issue has already 
been seriously advanced is disappointing but not reversible, no matter what she does to slow or stop the damage. Even during activities, she said that the climate change is a global phenomenon and that it is impossible for the whole world to try to stop it.

Eunmi: I'm going to think about saving the environment. I'm starting to think at the same time, anyway ...

Researcher: Anyway?

Eunmi: Yeah, what changes? Is this climate behavior meaningful? Actually, I know now how serious climate change is, and also, I know it is going too far. So, I think "Let's just have fun and then die?"

Researcher: So, what do you think about the activities we did, where we doing a good job of informing friends?

Eunmi: Actually, I don't think there's a very good way to make sure about climate change. I don't think climate action means anything. So, no matter how much I talk to my friends about climate change, it won't work ...

The competence of participation as an ecological citizen was the ultimate goal of the high school climate change club project and the ultimate ability that students hoped to cultivate. In the third step of the activity, students produced posters and participated in a campaign to publicize climate change problems, feeling proud and confident that they were the ones who could speak out for the problems happening around the world. However, since there have been some cases with negative views on the ongoing climate change situation, such as that of Eunmi, we feel that careful attention is needed when planning activities.

In this study, we developed and applied a three-step project activity in a high school climate change club for the purpose of fostering ecological citizenship. The purposes of the study were to explore the characteristics of students' activities and artifacts and how students' ecological citizenship changes after their participation in a club project. The participants were 10 students from a high school in a medium city near Seoul, Republic of Korea. Data were collected from pre- and post-questionnaires, students' artifacts during activities, researchers' field notes, and in-depth interviews after the activities. 
Based on the results, following conclusions were drawn. First, throughout the club activities, students' activities were very student centered or student led and interactive in small groups. However, the types of activities were different in each step depending on the nature of the step: co-construction of scientific models about the causes of climate change in the first step, small group investigations about a local issue chosen by each small group in the second step, and planning and execution of actions in the third step. Also, students produced various artifacts during club activities. Resources, such as drawings and writings when they were planning, developing reports during investigation, and making posters were all evidence of action taken to address climate change. These resources were all used for social action to evoke awareness of citizens' responsibility for the climate change. The students' final actions focused on raising awareness of the climate change crisis using posters inside of the school seemed to be feasible for them. However, it also showed that there might be some limitations to foster students' ecological competence because their actions only included posting posters inside of the school rather than taking authentic action against local issues on climate change and inviting wider participation.

Second, ecological citizenship among students generally improved substantially after participating in club activities. However, small or negative changes also occurred among a small proportion of students in three aspects of ecological citizenship: knowledge and understanding, justice, and participation. After participating the club project, students show competences in five aspects of ecological citizenship. First, in knowledge and understanding, the students learn and understand the causes and effects of climate change through participation in various activities, especially the modeling activities in Step 1. In the responsibility aspect, they come to view human beings responsible for the climate change crisis. In the justice aspect, students can become aware of international inequalities, such as those between Global North and Global South countries, and how those inequalities result in differential contributions to the emission of greenhouse gases. In terms of sustainability, project activities seem to provide students the opportunity to reflect on their daily individual behavior and encourage them change their behavior to become more environment friendly. Finally, in terms of participation, the majority of students revealed more willingness to participate and bring about real changes in their behavior. However, some students were disappointed with the current situation and anticipated a hopeless future.

The climate change club project activities developed and applied in this study appeared to have positive impacts on fostering competences in ecological citizenship among students. The results of the in-depth interviews reveal 
that participants had opportunities to look at the climate change issue in a new light, which allowed them to think about who is responsible for climate change, develop values, and consider ways of solving the problem. In addition, the awareness of the global effects of climate change can be expanded gradually, so that they can develop senses of their own positions in terms of justice and the ability to take personal and social actions for a sustainable society.

We included scientific knowledge and understanding in ecological citizenship. There have been debates about the role of scientific knowledge in environmental education. Tsevreni (2011) proposed an alternative approach in environmental education based on students' ideas and actions rather than scientific knowledge. Bishop and Scott (1998), however, argued the fundamental importance of scientific knowledge for environmental action. The club activity developed in this study includes scientific knowledge and understanding as the first step based on a scientific modeling approach because the researchers support the importance of scientific understanding and nature of science in climate change education. This is well aligned to Socio-Scientific Issues (SSI) education programs such as STEPWISE (Bencze, 2017), which includes research-informed and negotiated actions (RiNA) and Promoting Attainment of Responsible Research and Innovation in Science Education (PARRISE) with socio-scientific inquiry-based learning (SSIBL; Amos \& Christodoulou, 2018).

The findings of the study have contextual and practical implications. Fostering ecological citizenship is urgently needed considering the climate crisis at hand. However, climate change education for action requires an interdisciplinary and integrated approach that often crosses the existing system of divided subject matter boundaries and certified teachers in subject areas in schools. However, the club activity approach has the potential to avoid the inflexibility of school education systems by using extracurricular activities. Schedules can be organized relatively freely, students can have more leading roles in club activities, and fewer restrictions exist on the scope of activities. Students can be given the opportunity to learn about climate change, to think for themselves and develop their own values, and to develop the ability to practice in their own communities by working out solutions to any foreseeable problem that they may face.

Educational context may have negative impacts on students' participation in club activities. For example, in the test-oriented atmosphere of schools in Korea, high school students showed concerns about their academic performance and preparations for college entrance exams, even while participating in club activities. As a result, participating students were unable to carry out their activities during the final examination period, and although they were fully willing to participate in social practices, they thought that they would 
rather postpone their participation until after entering university. Students with comparable educational contexts, especially in East Asian countries, may show similar patterns.

Critical scientific literacy (Hodson, 2011), and Vision III of scientific literacy (Sjöström \& Eilks, 2017) have been suggested as new goals of science education. This study also tries to embrace some ways toward transformative science education in the global risk society (Beck, 1999/2010) for future citizens focusing on the urgent climate crisis. Because of the urgency of the climate crisis, opportunities in extracurricular activities were chosen in this study. However, considering the importance of the competences for ecological citizenship based on sound scientific understanding, we need discussions about how to reorganize and reform educational systems, including school curriculums and teacher certification and preparation.

\section{Abbreviations}

IPCC Intergovernmental Panel on Climate Change

PARRISE Promoting Attainment of Responsible Research and Innovation in Science Education

RiNA Rresearch-informed and Negotiated Actions

SSI Socio-Scientific Issues

SSIBL Socio-Scientific Inquiry-Based Learning

STEPWISE Science \& Technology Education Promoting Wellbeing for Individuals, Societies \& Environments

UNDP United Nations Development Programme

UNESCO United Nations Educational, Scientific and Cultural Organization

\section{Acknowledgements}

The researchers would like to thank the school, parents, and students for their participation in this study.

\section{Funding}

This work was supported by the Ministry of Education of the Republic of Korea and the National Research Foundation of Korea (NRF-2019S1A5A2A03048062) 


\section{Ethical Considerations}

Approval to conduct this study was granted by the Seoul National University Ethics Review Board. The data collected from this project has obtained the necessary clearance from the school, guardians and the students involved in the study. The names of the school and participants used in this study are all pseudonyms.

\section{About the Authors}

Woo-Yong Park is a graduate student in Science Education in the Earth Science Education department at Seoul National University in Seoul, Republic of Korea. His research focuses on climate change education at middle- and highschool levels. He is particularly interested in cultivation of ecological citizenship from new kinds of climate change education, such as activities in school club related to subject of climate change. He is interested in engaging students in climate change education to foster their own action competency regarding environmental issues.

Chan-Jong Kim is Professor in the Department of Earth Science Education at Seoul National University in Seoul, Republic of Korea. He received his bachelor's degree in Earth Science Education and master's degree in Geological Sciences from Seoul National University in the Republic of Korea. He also holds a doctoral degree in Science Education from the University of Texas at Austin in the United States. His research focuses on scientific modeling as an approach to scientific exploration and learning in a variety of subjects, contents, and contexts and on development and application of various methods for the analysis of collective talk with learning of science. He is particularly interested in education for diverse learners in Korean K-12 on global environmental risks such as climate change.

\section{References}

Amos, R., \& Christodoulou, A. (2018). Really working scientifically: Strategies for engaging students with socio-scientific inquiry-based learning (SSIBL). School Science Review, 371, 59-65.

Beck, U. (1998). The reinvention of politics (S. H. Moon, Trans.). Geoleum. (Original work published 1993). 
Beck, U. (2010). Global risk society (M. A. Park \& J. W. Lee, Trans.). Gil. (Original work published 1999).

Bencze, L. (Ed.) (2017). Science and technology education promoting wellbeing for individuals, societies and environments. Springer.

Bishop, K., \& Scott, W. (1998). Deconstructing action competence: Developing a case for a more scientifically-attentive environmental education. Public Understanding of Science, 7, 225-236.

Carter, N. (2001). The politics of the environment, ideas, activism, policy. Cambridge University Press.

Choi, D. H., \& Kim, C. K. (2008). Thoughts on the direction of climate change education in Korea [Paper presentation]. Conference of the Korean Society for Environmental Education, June 28, 2008, Seoul, Republic of Korea.

Dobson, A. (2003). Citizenship and the environment. Oxford University Press.

Giddens, A. (2009). The politics of climate change. (W. H. Hong, Trans.) Eco-Livres. (Original work published 2009).

Helm, J. H., \& Katz, L. G. (2001). Young investigators: The project approach in the early Years. Teachers College Press.

Hodson, D. (2011). Looking to the future: Building a curriculum for social activism. Sense. Hong, C. S. (2016). Ulrich Beck. Communication Books.

IPCC. (2014). Climate change 2014 synthesis report: Summary for policymakers. IPCC.

Karatekin, K., \& Uysal, C. (2018). Ecological citizenship scale development study. International Electronic Journal of Environmental Education, 8(2), 82-104.

Kats, L. G., \& Chard, S. C. (2000). Engaging children's minds: The project approach. Ablex Publishing Corporation.

Kim, B. Y. (2011). The implication of geographical and environmental education on debate about ecological citizenship. The Journal of the Korean Association of Geographic and Environmental Education, 19(2), 221-234.

Kim, B. Y. (2012). The ecological citizenship and environmental education in geography: "Relational geographies" discourses and applications. (Unpublished Doctoral dissertation). Korea National University of Education, Cheongju, Republic of Korea.

Kim, C.-J., Kim, M., Oh, H. S., Lee, J., \& Choe, S.-U. (2017). Understanding students' coconstruction processes of scientific modelling in Korean junior high school classrooms. In M. M. H. Cheng, A. Jones, \& C. Buntting (Eds.) Studies in science education in the Asia-Pacific region (pp. 40-55). Routledge.

Kim, C. K. (2013). Ecological citizenship and climate change education. Environmental philosophy, 16, 35-6o.

Kim, C. K., \& Choi, D. H. (2010). Thoughts on climate change education in Korea. Journal of Korean Society of Environmental Education, 23(1), 2-12.

Kim, H. K., \& Shin, J. H. (2012). An analysis on the curriculum and textbooks of environmental education: An interpretation from perspectives of ecological citizenship. 
Journal of Korean Association of Geographic and Environmental Education, 20(1), 125-141.

Kim, I. J. (2016). A study on development of a fossil exhibition program through the high school earth science club activity. (Unpublished Master's thesis). Korea National University of Education, Cheongju, Republic of Korea.

Kim, Y. G. (2009). Integrity analysis of elementary school textbooks on climate change and its responses. [Paper presentation]. Special Conference on the 2oth Anniversary of the Korean Society for Environmental Education, June 19-21, 2009, Seoul, Republic of Korea.

Korean National Commission for UNESCO. (2012). Comprehensive guide for field educators: Climate change education guide. Korean National Commission for UNESCO.

Krajcik, J., Blumenfeld, P., \& Soloway, E. (1994). A collaborative model for helping middle grade science teachers learn project-based instruction. The Elementary School Journal, 94(5), 483-497.

Ministry of Education. (2015). Creative experience activity curriculum (including safe living). Ministry of Education Notice 2015-74 [Separate Book 42].

Ministry of Education and Science Technology. (2009). High school environment and green growth curriculum commentary. Ministry of Education and Science Technology Notice 2009-41.

Oxfam. (2006). Education for global citizenship: A guide for schools. Oxfam Education.

Park, N. E. (2019). Analysis of climate change education programs: Focusing on cultivating citizen activists to respond to climate change. (Unpublished Master's thesis). Seoul National University, Seoul, Republic of Korea.

Shin, Y. J. (2017). Analysis on contents related to appropriate technology, sustainable development, climate change and energy of the 2015 revised national curriculum. The Korea Society of Energy and Climate Change Education, 7(1), 15-23.

Sjöström, J., \& Eilks, I. (2017). Reconsidering different visions of scientific literacy and science education based on the concept of Bildung. Cognition, Metacognition, and Culture in STEM Education: Learning, Teaching and Assessment, 24, 65-80.

Stern, N. (2006). Stern review: The economics of climate change. HM treasury.

Tsevreni, I. (2011). Towards an environmental education without scientific knowledge: An attempt to create an action model based on children's experiences, emotions and perceptions about their environment. Environmental Education Research, 17(1), 53-67.

UNDP. (2007). Human development report 2007/2008-Fighting climate change: Human solidarity in a divided world. United Nations Development Programme.

Yoon, S. J. (2009). The current state and tasks of school climate change education. The Environmental Education, 22(2), 1-22. 